\title{
Age Management: A New Paradigm In HRM Within Slovenian Enterprises
}

Jana Žnidaršič, University of Ljubljana, Slovenia, European Union

Vlado Dimovski, University of Ljubljana, Slovenia, European Union

\begin{abstract}
In the recent years a demographic situation in European countries has been mostly characterized by a growing proportion of the older population - a trend that is expected to continue in the future. The implications of this trend are not only present on the macroeconomic level (pensions, later retirement, health problems, etc.) but are more and more approached by the companies due to the aging workforce. Companies are thus introducing new approaches, policies and instruments which are synthetically called age management to accommodate to the situation of the ageing workforce. Age management is thus primarily the companies' orientation and is proved by the previous research that the essential drivers for the older workers staying active are found within the companies.

The aim of this paper is to highlight the development of age management within Slovenian companies where the practice of age management is still in its early stage. However, we expect that due to the ageing population and the shortages on the labor market one can expect that those practices will receive more and more attention in the future. Therefore, we reveal through the research of the 200 Slovenian companies the existing age management practices such as recruitment practices, training, remuneration, flexible work options, internal culture, and even a companies' external image.

We analyze the major problems and obstacles that seem to appear in developmental process of the age management implementation in Slovenian companies, and conclude with some recommendations for the future development of the age management.
\end{abstract}

Keywords: ageing of population, consequences of population ageing, active ageing approach within Slovenian enterprises, age management.

\section{INTRODUCTION}

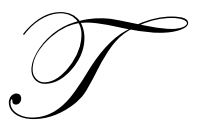

he European demographic situation - characterised by a growing proportion of older people has, over the last decade, emerged as a central priority for policymakers in the EU. This demographic shift calls into question both the sustainability of pension systems and the future of Europe's labour supply, which in turn raises questions about the prospects for economic growth. However, the implications of population aging are not only present on the macroeconomic level (pensions, later retirement, health problems, etc.) but are more and more approached by the companies due to the aging workforce.

In Slovenia, the response of policymakers, who have highlighted the need for initiatives to foster active ageing is somehow laging behind the "old" Member States (EU15), where policies and practices aimed at improving opportunities for older people have developed significantly in recent years. Although public actors have devised policies targeting such workers, the measures have not been sufficiently specific to contribute substantially towards fostering active ageing. Moreover, employers in Slovenia are still sometimes reluctant to employ older workers (Mandl, Dorr, Oberholzner, 2006). Nonetheless, the findings do indicate that the situation is beginning to change. In particular, there appears to be a greater level of understanding of the issue at company level, especially among the larger companies. Some of them are thus introducing new approaches, policies and instruments which are synthetically called age management to accommodate to the situation of the ageing workforce with the aim to provide an environment in which each individual is able to achieve his or her potential without being disadvantaged by their age. 


\section{THE STATUS OF OLDER WORKERS ${ }^{1}$ ON SLOVENIAN LABOR MARKET}

Slovenia is a small southern European country where manufacturing, financial intermediation/real estate and public administration constitute the most important economic sectors, characterised by a comparatively older population (if compared to the European average: EU-25), with the proportion of older people in the workforce being around $25 \%$, and a lower share of older than younger people among the unemployed population.

Due to comparability of unemployment with other countries it is worth mentioning that the rate of survey unemployment (calculated according to Eurostat methodology) in 2006 was $6.0 \%$. In the European Union (EU-25), the unemployment rate was $7.9 \%$, which means that the Slovenian survey unemployment rate was lower than the European average (Employment Service of Slovenia, 2006).

Chart 1: Registered unemployment trends, 1990 to 2006

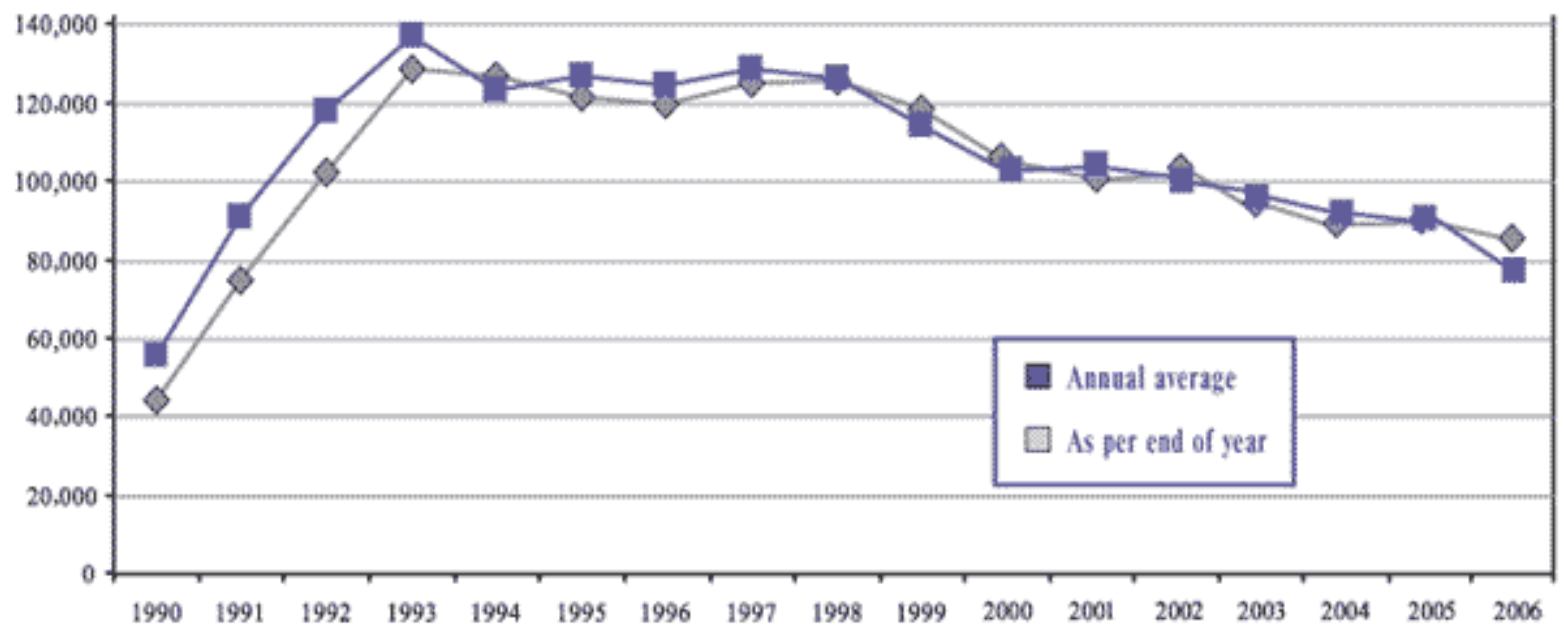

Source: Employment Service of Slovenia, 2006

There are some factors and problems that condition the situation on the labor market in Slovenia such as (Government of Slovenia, 2006): (1) educational, vocational and regional discrepancies; (2) massive inflow of unskilled labor force from the education system as a consequence of a high drop-out rate in vocational schools; (3) high share of moonlighting; (4) lack of suitable institutions which could, to a certain extent, guarantee modern approaches to training and retraining labor force; (5) insufficient participation of adults in educational and training programs; (6) obstacles to establishment and development of SMEs etc. Among the listed problems, a huge number of unemployed people in "risk groups" such as those aged over 45, persons with the reduced employability due to medical or other reasons, disabled persons - stands out. Their share represents nearly a half of all unemployed persons.

The age group around 50 years and over seems to have quite limited job opportunities. In Slovenia, this age group is widely deemed unattractive as a source of labour for a number of reasons: a perceived lack of flexibility and initiative; a poor grasp of foreign languages; a reluctance to take part in training; limited adaptability to new working conditions; a lack of knowledge of new technologies or production processes; and a greater tendency

\footnotetext{
${ }^{1}$ Slovenian employment legislation defines the ageing workforce as employed people aged 55 years and over (Slovenian Employment Relationship Act). Hard-to-employ are: (i) unemployed people aged over 50 which are registered at the Employment Service of Slovenia for more than 6 months, and (ii) people aged over 45 whose highest educational attainment is a secondary school degree and who are long-term unemployed (Regulation on implementation of active employment policy measures 2001).
} 
towards taking sick leave. The employers' percepcion of older workers in our country is actually very influented by different stereotypes and myths. Only a few employers are aware of the fact, that (early) dismissal of the older population as a potential workforce represents a premature and permanent loss of human capital, as older people could represent a rich source of skills and experience. Of course, there are other reasons beside stereotyping, that hinder older workers from staying active, and bed labor market flexibility is one of the most signifficant reasons for early retirements, since Slovenia has less than $10 \%$ of working-population, being part-time employed (Kajzer, 2005).

Another reason for extremely low participation of older workers on Slovenian labor market we cannot ignore it is the transformation period in early 1990s. Transformation depression was accompanied with decline in economic activity in general and inflation, which both had negative impact on employment. Labor market conditions have radically changed. Many enterprises faced inevitable failure, many workers were dismissed, and it was not easy any more to find a job. The registered unemployment rate was rising up to $14.4 \%$ in 1993 . The most critical groups were those having no vocational education, older than 40 (the share of those over 40 increased from 17\% in 1987 to $46 \%$ in 1998) and those already being unemployed. The significant change was observed in structural proportions of economic sectors and in changing composition of the work force. Transformation depression has increased the demands for educated employees; those without having qualifications mostly lost their jobs. The problem was moderated with new retirement legislation, which enabled the possibility of early retirement. In time period between 1988 and 1992, the number of work force decreased for 150,000 people as the consequence of retirements. The percentage of retired among whole population was $16.7 \%$ in 1987, and has increased up to $22.2 \%$ by the year 1992 (Pirher et al., 2000, p. 15). In 1992, two active people came per one retired. Consequently, taxations increased and competitiveness of firms decreased. In 1993 the trend of retirement turned down, because the legislation has changed, the retirement age went up to 58 years for women and to 63 years for men. In spite of many negative consequences of to-early retirements, it was estimated, that if people who had been early retired joined to those being unemployed, the percentage of registered unemployment would be for $36 \%$ higher in the middle of 1991 (40\% in 1992), than it actually was (Mencinger, 1997).

Chart 2: Employment rates of persons aged 55-64, EU-25, 2000 - 2005

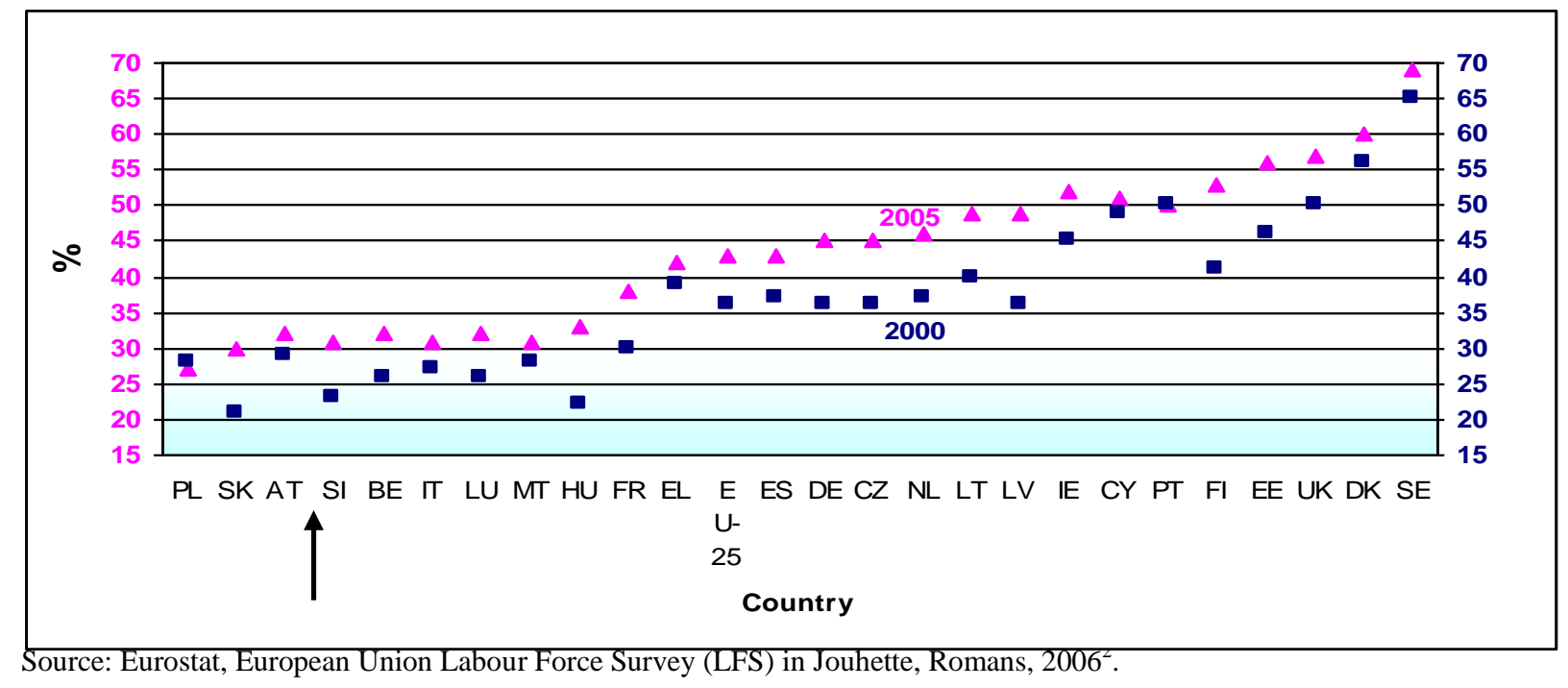

\footnotetext{
${ }^{2}$ Country codes applied in Chart 2: BE (Belgium), CZ (Czech Republic), DK (Denmark), DE (Germany), EE (Estonia), EL (Greece), ES (Spain), FR (Metropolitan France, excluding the 'Départements d'Outre-Mer', i.e. Guadeloupe, Martinique, Guyane and Réunion), IE (Ireland), IT (Italy), CY (Republic of Cyprus), LV (Latvia), LT (Lithuania), LU (Luxembourg), HU (Hungary), MT (Malta), NL (Netherlands), AT (Austria), PL (Poland), PT (Portugal), SI (Slovenia), SK (Slovakia), FI (Finland), SE (Sweden), UK (United Kingdom), EU-25 (European Union).
} 
On that point, we must emphasise that, recent trends are completely reverse, as pre-retirement schemes are being replaced with the postponement of pension age - encouraging flexible employment and gradual retirement, as an extremely low participation of older workers on Slovenian labor market urgently calls for imidiate action. In year-group 55-64, there was only 23.5\% people employed in the year 2004 (Kajzer, 2004), which is much faraway from Lisbon strategy - planning the 50\% employment by the year 2010 in the same age-class, and even far from EU-15 average, which is $41.7 \%$ and EU-25 with $40.2 \%$. In Denmark, Estonia, Portugal, Finland, Sweden and the United Kingdom, the rate in the year 2004 was higher than 50\%. In France, Latvia, Hungary, the Netherlands and Finland, the rates increased by at least 7 percentage points compared to 2000. Four countries remained below 30\%: Poland (-2.2 p. p.), Austria (unchanged), Slovakia (+ 5.5 p. p.) and Slovenia, where the employment rate of older people increased by 6.3 p. p. in 2004, compared to 2000 (Jouhette, Romans, 2005). However, in 2005 the share of those being employed in the year-group 55-64 is still low, 30.7\%, with only $18.5 \%$ of women being employed (Jouhette, Romans, 2006). By sector, the highest proportions of older employees can be found in the public administration, education, health and other services sectors, the lowest proportion of older workers is in the hotel and restaurant sector (Mandl, Dorr, Oberholzner, 2006).

However, there exist problems that older people are confronted with on the labour market in Slovenia. Some main problems could be summarised as follows (Pušnik at al., 2006):

- Employment legislation does not sufficiently protect the older workforce from dismissal because of the company's reorganisation (in practice, companies dismiss older employees more often than younger ones).

- There is no efficient consultancy for older unemployed people at employment services because consultants are overburdened.

- Human resource management and employment policy of companies and other organisations is discriminatory. The reasons are the fear of older employees of loosing their jobs, the need of companies to accommodate to new technology, the passive role of unions in defending the rights of the ageing workforce and older unemployed people and the unwillingness of some companies to employ older people.

- Disabled older unemployed workers face additional problems because of their disability: older people represent the largest part of disabled workers.

- $\quad$ Older unemployed people have psychological problems (low self-esteem, negative self-image, lack of socialisation, loss of skills and work habit etc.).

The loss of a skilled and experienced labour force, particularly in those sectors with a high proportion of older employees, might cause a decline in economic growth. In view of Europe's diminishing younger population, companies will have to increasingly rely on older workers or otherwise run the risk of losing business opportunities due to labour shortages.

\section{AGE MANAGEMENT IN SLOVENIA: MACRO LEVEL}

There were already some public initiatives for older workforce in the 1970s and 1980s, but they were mainly aiming at improving education, knowledge and employability of adult population and particularly the quality of living.

Before the end of 1990s, employment policies and the organization of pension system were more stimulating inactivity of older workforce. As aresult, strategies and policies for encouraging older workers to remain in employment (i.e. active employment strategy) have been established and the laws (Pension and Disability Act, Employment and Insurance against Unemployment Act) have been changed.

In Slovenia, the ageing workforce has been essentially backed by the government through employment policy since the end of the 1990s, and by activities performed by different actors in the field of adult education and life long learning. Most of the direct activities were designed to promote employment of older persons are carried out within the measures that stimulate employers to create new jobs, employment of disadvantaged people and training and education for employment. 
More sound public discussion about employment initiatives for an older workforce arose at the end of the 1990s, as part of the framework of the Active Employment Policy (aimed to employ "hard to employ groups"). However, only in 2005 were the active employment policy schemes designed to address the problems of people aged 55 years and over. Ageing workforce issues are tackled in the Strategy for the Economic Development of Slovenia 2001 - 2006 (SEDS), Slovenia's Development Strategy 2006 - 2013 (SDS) and, partially, in sectoral and regional development strategies, national programmes and other development documents based upon the SDS and SEDS.

In preparing the Strategy ministries and expert groups by programme areas were involved. The Strategy was also subject to public debate that included employers' and employees' associations, NGOs, representatives of regional and local interests. Relevant proposals arising from the public debate were included in the final document. In order to prevent and suppress problems and consequences related to ageing workforce SDS and SEDS have foreseen measures that increase citizens' motivation, capability and work possibilities (SEDS 2001, SDS 2005):

- Motivation for activity includes introducing bonuses and penalties in the pension insurance to stimulate longer activity, reforming social assistance programmes, linking social security benefits to a system of active help, relieving the citizens of the tax burden and obligations and institutionalising people's greater personal responsibility for their own social status;

- $\quad$ Ability (capability) for activity includes protecting workers' health, life-long learning, training, acquiring knowledge and skills, assuring on-job health and safety;

- $\quad$ Possibilities for work include adjusting the working conditions for older employees and changing attitudes towards them, acknowledging their activity, reduce employers' social security contributions for older workers.

However, the progres of age management implementation seems to be slow and in comparison with other EU countries, especially EU-15, Slovenia is still lagging behind when considering participation of older workers on the labor market, which is low. This fact pinpoints the necessity of specific public and private initiative aimed at improving the integration of older persons in the labour market.

The Slovenian government (in connection with employers and unions) is planning to further enhance the employability of long-term unemployed people over 55 years of age through the introduction of active employment policy programmes. The social partners have recently welcomed the programme of active employment policy measures for the 2007-2013 period and an action plan for the first two years of implementation. According to the Labour Ministry, the programme has now been brought into line with the programming documents that serve as the basis for the phasing of money from the European Social Fund in the 2007-2013 period. The active employment policy programme is divided to four main measures: assistance in job searching (including career planning), training and education, promotion of employment and self-employment, and programmes to boost social inclusion. At present, a particular strategy to foster employment of the older workforce and active ageing is being adopted in Slovenia, according to the National Action Plan for implementation of Lisbon Strategy, adopted at the end of October 2005 and now subject to discussion are:

- $\quad$ rise of retirement age according to the 1999 pension reform;

- $\quad$ adoption of comprehensive active ageing strategy;

- $\quad$ enabling access to education, training and life-long learning and thereby substituting quantity of labour force with quality;

- development of integrated employment programmes for older-workforce, establishment of working-places in social economy (quasi market) and development of system that would enable older workforce employment in "normal" economic environment.

The main public actor in the field of employment initiatives for ageing workforce is The Ministry's of Labour, Family and Social Affairs responsible for the arrangement and implementation of laws and other legislation in the area of employment, labour relations, on-job health and safety, pension and disability insurance, insurance against unemployment, employment and status of disabled persons and social inclusion. Also other ministries are responsible for policies that foster greater employment of the older workforce. The duties of The 
Ministry of the Economy in increasing the employment of the older workforce are predominantly connected to promotion of entrepreneurship. In the future the ministry is planning to promote employment via social entrepreneurship. The Ministry of Health is responsible for preparing the health insurance legislation, on-job health and safety and public health. By now, the ministry has levelled programmes on the whole population, old people after retirement (social care) and special target groups (patients with certain diseases, people with addiction problems etc.). The Ministry of Education and Sport has the responsibility for the school system from pre-school education and (upper) secondary to post-secondary education. It is responsible for both, initial and adult education. The Ministry of Finance has to check the availability of financial resources. he central implementing institution for employment policy in Slovenia and the most mportant mediator between current supply and demand in the labour market is the Employment Service of the Republic of Slovenia (ESS). It implements activities which lead to decreases in the number of unemployed and a reduction in the structural disparities in the labour market. The ESS also implements programmes in Slovenia which are co-financed by the European Social Fund (increasing employability, ensuring social inclusion, the creation of new jobs and increasing the adaptability of enterprises), and as a partner, participates in the projects of the EQUAL initiative.

\section{AGE MANAGEMENT IN SLOVENIA: COMPANY LEVEL}

As already indicated, older workers in Slovenia have been disadvantaged in the labour market, mostly due to the dramatic restructuring in the transition period. The majority of workforce redundancies were older workers, however those redundances were hidden behind the early retirements. Eighteen years ago, at the beginning of the conversion of the socialist economy to a market economy, the number of pensioners increased significantly. Amongst them, numerous pre-pensioners served the purpose of buying social peace. On the other hand, our research study has shown that a vast majority of the older workers themselves would like to withdraw from the labor force at the earliest possible opportunity.

With a total unemployment rate of $10 \%$, it was difficult to explain the necessity of putting older workers back in business, particularly as the policies for fighting against unemployment have often consisted of pushing the oldest workers toward pre-retirement. For too long older workers have been the adjustment variable in reorganisations and only recently, managers became aware of the need to break these bad habits.

Since then new institutional and legal possibilities have been adopted, however not being efficient very much in solving the problem of the employment of seniors, since the employment rate of old people is still very low. In this sense, the Slovene situation can be viewed as the heritage of the past.

With certain delay, Slovenia became aware of some problems, connected with aging population and aging workforce - more present at company level. It seems that the impact of ageing on public expenditure and economic growth rates were the leading drivers for age management development in Slovenia, underlining the need to extend working life, which goes hand in hand with inevitable fact that employers will have to employ more, both in absolute and in relative terms, over-50s and over-55s in the future. Accompaned with some other principal reasons, such as tackling age barriers and discrimination, age management started to be seen as an economic and social necessity. However, the implementation of age management at company level is legging behind the most developed European countries. Consequently, there is very limited research on what is actually being done.

This is why we have recently done a pioneer research in this field and this paper discusses the current status of strategic responses and implementation programs being delivered to engage retain and recruit our ageing labour force by Slovenian employers. This article focuses on the role played by employers, since most decisions on how to deal with an aging workforce will have to be taken within individual organizations, or will, at least, be implemented within these organizations (Remery et al, 2003).

Our research addresses four research questions:

1. 1 What do employers see as the main drivers for working on retention of their aging workers?

2. Which measures are employers taking to recruit or retain older workers?

3. What are the principle aims of implementing HRM measures targeting older employees? 
4. What are the reasons for not being inclined to employ or retain older workers?

The answers to these questions will shed light on the degree to which employers in Slovenia are aware of the inevitable aging of the labor force and its implications for the labor market and for individual employers.

\section{AGE MANAGEMENT DRIVERS IN SLOVENIAN COMPANIES}

The drivers which make age management practices reasonable are more or less the same within European countries. One of the main reasons that force employers to combat age barriers is age discrimination, which has been called the last unrecognised discrimination, including both open and hidden forms (Walker, 1998). For example, older workers are experiencing more long-term unemployment and get less training than younger ones.

At the same time there is a plethora of scientific evidence to show that older workers are no less effective than younger ones - though of course there are variations between jobs. Older staff also have fewer accidents than younger ones and are less likely to leave an organisation. Their average net cost to an employer is similar to that of younger staff or very often cost-benefit analisis talks in favour of older employees (Brooke, 2003). In addition there are pragmatic reasons why the social partners are beginning to look for ways of removing or reducing the impact of age barriers. Some employers have even begun to articulate a 'business' case in favour of older workers. Some main reasons - why tackle age barriers include (Walker, 1998): (1) the age structure of the workforce is changing rapidly in all countries. That fact implies a radical change in human resource strategies and a new approach to managing age at the workplace. Future competitiveness will rest partly on the performance and productivity of ageing workforces and, therefore, on the efficient utilisation of older workers; (2) at plant level employers are reassessing the consequences of early exit. It is being seen by some as a waste of experience and human resources and of the investment they have made in the workforce. Others see roles for older workers in training younger people or in preventing skill shortages; (3) there is growing awareness among employers and trade unions that, by artificially limiting the field of candidates, age barriers prevent an organisation from maximising its recruitment potential; (4) some enterprises are recognising that the organisation with a diverse age base - a mixture of youth and maturity - is likely to be able to respond best to rapidly changing circumstances. In the service sector in particular, employers are seeing the benefits of adjusting the age range of their employees to better reflect the age composition of their customers; (5) there are widespread government concerns about employment rates and the financing of pensions. Especially in Slovenia the effect of early leaving employment has been even more present since Slovenia has gone through its tranzition period in which early retirements seemed to be the most elegant way of reducing employees.

\section{AGE MANAGEMENT IN SLOVENIAN COMPANIES: EMPIRICAL EVIDENCE}

As we have already said, in our recent research, we have been following the aim to get as much clear picture as possible about what was going on considering age management at company level in Slovenia. The basic aim of the survey was to study the degree to which employers are taking measures to improve the employability of older workers or simply to retain them in employment longer. The respondents were presented with a list of measures and asked to indicate whether their organization was implementing these measures or was considering doing so. The list was based on some earlier studies into age-conscious personnel policies (Nunn, Wymer, Fidler, 2006; Remery et al., 2003; Robson, 2001; van Dalen et al., 2006).

The empirical research methodology was carefully considered and finally we have used a mixed strategy of approaching organisations, which means that the quantitative and qualitative parts of research were conducted simultaneously. With the aid of data provided by a large-scale survey conducted among 870 companies and three case studies in Slovenian entreprises, we were able to answer on four research questions. Within quantitative research, 870 Questionnaires - based on the theory outlined above - were sent by post mail to organisations. Based on informal telephone communication with HRM in Slovenian companies, we chose three large companies for casestudies, and thus face-to-face and telephone interviews were also carried out within qualitative research. Data collection took place from September 2007 to December 2007.

In September 2007, a questionnaire given the title "New perspectives in HRM practices within Slovenian entreprises in the context of active aging" was sent to 870 companies with more than 100 employees. The names and 
addresses of these organizations were taken in part from a sample drawn from the trade register of the Chamber of Commerce. Where possible, the questionnaire was addressed to a named Human Resources contact in each of the sampled organisations. Where this was not available, the questionnaire was addressed to 'The HR Manager'. A covering letter explained the purpose and importance of the research, however it emphasised the annonimus approach in order to reduce socially desirable answers.

The total response rate was 28 percent, which is higher than the response generally found in corporate surveys in Slovenia whereas it is simillar than response rates in Europe and the United States, where they have been found to be at most 20 to 30 percent. The questionnaires were completed by human resouce managers, head of personnel or by a board member/managing directors or the owner. The questionnaires included a number of general factual questions about the organization and the age structure of the workforce, as well as specific questions about the position of older workers and the implications of an aging workforce.

The first part of the questionnaire refers to the extent organizations faced labor shortages and the other problems that arose from an aging labor force. The central part of the questionnaire consists of a number of questions about the degree to which employers implement age management activities and the last part of the questionnaire comprises questions about the reasons for not having the interest for employing (retaining) older workers.

\section{KEY FINDINGS}

To get the answer to the first research question »What do employers see as the main drivers for working on retention of their aging workers?", we proposed a variety of ideas and asked HR managers to rate the importance of certain reasons (problems), using a five-point Likert scale (from 1 - not important at all to 5 - very important).

From Table 1, it is understood that HR managers have given the highest values to reasons, such as: (1) special knowledge and experiences retention - possesing by older workers; (2) the need to transform expertise on successors; (3) benefiting from older workers' characteristics - strenghts, such as: having experiences, responibility, loyalty etc.; and (4) general labor shortages on the labor market (shortages of younger candidates).

An interesting question on that poin is whether the drivers that influence older workers retention for individual organizations can be grouped into different dimensions. In other words, do certain "problem situations" that call for implementing age management actions occur in concert, and do companies differ from one another in this respect? For example, whereas certain types of organizations might emphasize the business reasons for older workforce retention, other types of organizations may attach greater importance to the labor market shortages. The existence of dimensions can best be studied with the aid of factor analysis.

Factor analysis studies how the answers with respect to the drivers can be grouped into categories on the basis of the relationship found between the various answers given. The results show that the drivers that call for aging workforce retention can be grouped into three dimensions: business purposes, external drivers and labor market problems - mostly concerning labor shortages. These three dimensions will be briefly described below.

Drivers that constitute the first dimension - named "internal business purposes" are as follows: (1) costs saving (saving recruting and candidate-development costs), (2) mentoring, coaching and tutoral roles needs, (3) talent retention, (4) special knowledge and experiences retention - possesing by older workers, (5) the need to transform expertise on successors, (6) keeping good contacts with customers, (7) better adapting to customers' age profile and their special needs (customers age getting older, too), (8) getting competitive advantages from agemixed workforce, (9) organizational culture retention and development, (10) high work etics retention among employees (commitment, loyalty etc)., (11) benefiting from older workers' characteristics - strenghts, such as: having experiences, responibility, loyalty etc. and (12) the need to finish certain projects, that are led by older staff. 
Table 1: Potential reasons or problem-situations that drive HRM to work on retention of older workers

\begin{tabular}{|c|l|c|}
\hline \multicolumn{2}{|c|}{$\begin{array}{c}\text { Potential Reasons (Problem Situations), That Drive Hrm To Implement Actions Aiming At Older } \\
\text { Workforce (50 Years Or More) Retention }\end{array}$} & $\begin{array}{c}\text { Importance } \\
\text { (mean values) }\end{array}$ \\
\hline $\mathbf{1}$ & General labor shortages on the labor market (shortages of younger candidates) & $\mathbf{3 , 6 4 7 1}$ \\
\hline $\mathbf{2}$ & Preventive action against potential labor shortages in future & 3,1144 \\
\hline $\mathbf{3}$ & Cost saving (saving recruting and candidate-development costs) & 2,3448 \\
\hline $\mathbf{4}$ & $\begin{array}{l}\text { Succession management difficulties: shortage of candidates to replace positions held by older } \\
\text { workers }\end{array}$ & 2,9257 \\
\hline $\mathbf{5}$ & Mentoring, coaching and tutoral roles needs & 3,0788 \\
\hline $\mathbf{6}$ & Talent retention & 3,4080 \\
\hline $\mathbf{7}$ & Retention of special knowledge and experience possessed by older workers & $\mathbf{3 , 8 8 1 8}$ \\
\hline $\mathbf{8}$ & The need to transfer expertise to successors & $\mathbf{3 , 8 2 6 7}$ \\
\hline $\mathbf{9}$ & Keeping good contacts with customers & 3,2915 \\
\hline $\mathbf{1 0}$ & $\begin{array}{l}\text { Better adaptation to customers' age profile and their special needs } \\
\text { (customers age getting older, too) }\end{array}$ & 2,4700 \\
\hline $\mathbf{1 1}$ & Getting competitive advantages from age-mixed workforce & 3,0945 \\
\hline $\mathbf{1 2}$ & Organizational culture retention and development & 3,0347 \\
\hline $\mathbf{1 3}$ & Keeping high work ethics among employees (commitment, loyalty etc). & 3,4901 \\
\hline $\mathbf{1 4}$ & Benefiting from older workers' strenghts including experience, a sense of responibility and loyalty & $\mathbf{3 , 6 4 8 5}$ \\
\hline $\mathbf{1 5}$ & The need to finish the projects led by older staff & 3,0396 \\
\hline $\mathbf{1 6}$ & The increased need for workforce during holiday seasons & 2,2462 \\
\hline $\mathbf{1 7}$ & $\begin{array}{l}\text { Building a reputation of a socially responsible company; becoming an "employer of choice", } \\
\text { employing different workers, regardless of age }\end{array}$ & 2,7871 \\
\hline $\mathbf{1 8}$ & Changing labor legislation & 2,8480 \\
\hline $\mathbf{1 9}$ & New trends in planning retirement - gradual retirement pathways. & 2,7921 \\
\hline
\end{tabular}
Source: Žnidaršič, 2008.

The second group, entitled "external drivers" that influence on the organisation from outside includes the following drivers: (1) the need for more workforce during seasons or holidays, (2) building the reputation as socially responsible company; it means being an "Employer of choice" - employing different workers, regardless of age, (3) changing labor legislation and (4) new trends in planning retirement - gradual retirement pathways.

The last dimension - named "labor shortages", consists of: (1) general labor shortages on the labor market (shortages of younger candidates), (2) preventive action against potential labor shortages in future and (3) succession management difficulties: shortage of candidates that would replace older workers' possitions.

The second research question about which measures are employers taking to recruit, retain or simply to meet the special needs of older workers was answered with the aid of proposed actions upon them the employer had to choose wether certain measure: a) is being implemented; b) is cinsidered to be implemented or c) would not be considered for implementation (Table 2).

The results in the Table 2 indicate that the most widely implemented measures, starting with age-neutral advertising of job vacances ( $86.6 \%$ of organization are already implementing this measure), were found to be those aimed at accommodating older staff with multigeneration team-building (67\%), preventive medical checks (64\%), risk identification at workplace (58.4\%), communicating about retirement plans (62.4\%), communicating options to prolong working life (56\%), knowledge identification and transformation (53.3\%), exemption from working overtime for older workers $(50 \%)$.

Whilst some of the respondents did not implement any of these age-conscious policy measures (or at least they have not provide us with any answers), employers were found to implement an average of ten of the measures mentioned. 
Table 2: Percentages of Slovenian employers implementing measures - targeting older employees

\begin{tabular}{|c|c|c|c|}
\hline Measures Targeting Older Employees & $\begin{array}{c}\text { Being } \\
\text { implemented }\end{array}$ & $\begin{array}{l}\text { Considered to be } \\
\text { implemented }\end{array}$ & $\begin{array}{c}\text { Not to be } \\
\text { considered }\end{array}$ \\
\hline No age-barriers in job advertising & 86,6 & 1,5 & 11,9 \\
\hline Introducing awareness programes combating age stereotypes & 14,4 & 19,5 & 66,2 \\
\hline Promotion of active aging strategies & 3,6 & 30,8 & 65,6 \\
\hline Educating managers about age management & 6,2 & 27,3 & 66,5 \\
\hline Forming additional market value on behalf of older staff & 29,6 & 21,9 & 48,5 \\
\hline Career development (planning) with older staff & 44,2 & $\mathbf{3 8 , 7}$ & 17,1 \\
\hline Succession planning & 47,8 & 39,3 & 12,9 \\
\hline Communicating about retirement plans & 62,4 & 19,8 & 17,8 \\
\hline Partial (gradual) retirement options & 34,3 & 25,4 & 40,3 \\
\hline Additional leave/increased holiday pre-pension & 19,3 & 9,9 & $\mathbf{7 0 , 8}$ \\
\hline Prolonged career interruptions (sabbaticals) & 7,0 & 8,0 & 84,9 \\
\hline Age limits for irregular work (holidays, weekends) & 22,6 & 7,7 & 69,7 \\
\hline Exemption from working overtime for older workers & $\mathbf{5 0 , 0}$ & 9,0 & 41,0 \\
\hline Exemption from working in shifts for older workers & 34,7 & 9,0 & 56,3 \\
\hline Flexible working hours & 25,9 & 15,4 & 58,7 \\
\hline $\begin{array}{l}\text { Flexible working practices (at home, compressed working } \\
\text { week etc.) }\end{array}$ & 10 & 18 & 72 \\
\hline Adapting work (job) to person & 20,6 & 27,6 & 51,8 \\
\hline Reducing workload for older workers & 11,9 & 14,9 & 73,1 \\
\hline $\begin{array}{l}\text { Placing older workers to a lower rank with a loss of salary } \\
\text { (demotion) }\end{array}$ & 9,5 & 14,4 & 76,1 \\
\hline $\begin{array}{l}\text { Programs covering the need to care for the older relatives or } \\
\text { children }\end{array}$ & 11,4 & 10,4 & 78,1 \\
\hline Continuous assessment of (older) workers & 11,5 & 16 & 72,5 \\
\hline Training programs for older workers & 17,5 & 19 & 63,5 \\
\hline Knowledge identification and transfer & 53,3 & 27,6 & 18,6 \\
\hline Role changing for older workers: mentor, coach & 43,7 & 32,2 & 24,1 \\
\hline Multigeneration team-building & 67 & 19,5 & 13,5 \\
\hline Ergonomic measures & 39,5 & 23,5 & 37 \\
\hline Communicating options to prolong working life & 56 & 19 & 25 \\
\hline Paying additional health insurance & 31,2 & 8,4 & 60,4 \\
\hline Risk identification at workplace & $\mathbf{5 8 , 4}$ & 13,9 & 27,2 \\
\hline Preventive medical screening & 64,5 & 15,3 & 20,2 \\
\hline Promoting healthy living & 29,6 & 25,1 & 45,3 \\
\hline Fitness and wellness facilities. & 16,8 & 14,4 & 68,8 \\
\hline
\end{tabular}

Source: Žnidaršič, 2008.

The least implemented was promotion of active aging strategies (3.6\%), prolonged career interruptions sabbaticals $(7 \%)$, educating managers about age management $(6.2 \%)$, reducing older workers to lower ranks and a loss of salary $(9.5 \%)$, flexible working practices, such as working at home, compressed working week, working during seasons etc. (10\%). The empirical analysis, providing us with those results confirms the fact that age management is very poorly developed within Slovenian companies. Only 30.8 percent of organization say they are going to consider promotion of active aging strategies and 65.6 percent say that specific measure would not be even considered.

As for the measures that employers said they were considering, or said they might consider implementing in the near future, succession planning topped the list, at 39.3 percent, followed by career development (planning) with older $(38.7 \%)$, and role changing for older workers: mentor, coach $(32.2 \%)$. These relatively high percentages indicate that many employers expected that their aging workforce, or the prospect of an aging workforce, would necessitate adjustments to their personnel policies, with the emphasize on succession and knowledge management in the context of aging workforce. 
However, it should be noted that there are several age management measures that companies obviously do not pay any attention, since there are very high percentages of companies which do not even consider about the implementation of specific measure. Prolonged career interruptions were not seen as an option by many employers, 84.9 percent will not consider to implement that measure. Some results even leave us with fearful feelings, proving that not only individual company but the whole society is facing unpreparedness for aging society. 78.1 percent of companies said they did not intend to implement any programs covering the need to care for the older relatives or children. Demotion is also a measure that a majority of the employers said they did not intend to implement (76.1\%) and $73.1 \%$ would not consider to implement reducing workload for older workers.

There are more measures, such as: continually accessing the results at work (72.5\%), flexible working practices, such as working at home, compressed week etc. (72\%), additional leave/increased holiday pre-pension (70.8\%), age limits for irregular work - for example on holidays, weekends etc. (69.7\%), offering fitness and wellness facilities (68.8\%), that were not seen as an option by many employers either. Moreover, as high percentage as $63.5 \%$ stays for training programs for older workers, that organization are not concerned about. Similarly, $66.5 \%$ of companies are saying they would not intend to consider about educating managers about age management, introducing awareness programes, combating age stereotipes (66.2\%) and promotion of active aging strategies $(65.6 \%)$.

After examining the measures companies are implementing with the aim of targeting older workers, we cannot avoid focussing on the potential results companies associate with their age management policies (Table 3 ).

Table 3: Potential results (aims) of age management measures implementation

\begin{tabular}{|l|l|c|}
\hline \multicolumn{2}{|c|}{ Potential Aims Of Age Management Measures Implementation } & $\begin{array}{c}\text { Importance Of Certain Aim } \\
\text { (Mean Values) }\end{array}$ \\
\hline $\mathbf{1}$ & $\begin{array}{l}\text { Better meet the specific needs of older workers and thus enable them to remain } \\
\text { employable and able to perform well at the work place }\end{array}$ & $\mathbf{3 , 4 0 2 0}$ \\
\hline $\mathbf{2}$ & Prevention against going to another employer or deciding about early retirement & $\mathbf{3 , 1 0 8 9}$ \\
\hline $\mathbf{3}$ & Retention of older employees - stimulating them to postpone their retirement & $\mathbf{2 , 5 9 4 1}$ \\
\hline
\end{tabular}

Source: Žnidaršič, 2008.

In Table 3, we can see, that the majority of companies are introducing age management to better meet the specific needs of older workers and thus enable them to remain employable and able to perform well at the work place. The second reason was prevention against going to another employer or deciding about early retirement. It is somewhat surprising, that the retention of older employees - stimulating them to postpone their retirement was not a very common reason, even though many employers are already facing labor market shortages. That fact tells us that Slovenian employers do not see older employees as a good alternative to young employees. Moreover, they seem to be reluctant about retaining older employees. The main reasons for reluctance are presented in Table 4.

Table 4: Potential reasons for expressing the reluctance about employing or retaining older workers

\begin{tabular}{|c|l|c|}
\hline \multicolumn{2}{|c|}{ Potential Reasons - Expressing Reluctance About Employing Or Retaining Older Workers } & $\begin{array}{c}\text { Importance Of } \\
\text { Certain Reason } \\
\text { (Mean Values) }\end{array}$ \\
\hline $\mathbf{1}$ & No compelling business purpose & 3,2267 \\
\hline $\mathbf{2}$ & Retaining all employees - regardles of age - is of equal importance & $\mathbf{3 , 3 0 2 6}$ \\
\hline $\mathbf{3}$ & More pressing need for young blood & $\mathbf{3 , 9 4 8 1}$ \\
\hline $\mathbf{4}$ & The nature of work (hard workloads, unsuitable for older workers) & $\mathbf{3 , 8 8 9 6}$ \\
\hline $\mathbf{5}$ & Greater affordability of younger workers & 2,7616 \\
\hline $\mathbf{7}$ & Abundant supply of workers under current arrangements or even the need to reduce the staff & 2,0915 \\
\hline $\mathbf{8}$ & Letual and/or anticipated opposition from workers and/or managers & 2,4067 \\
\hline $\mathbf{9}$ & Have not considered it & 2,3904 \\
\hline
\end{tabular}

Source: Žnidaršič, 2008. 
In summary, this research suggests that employers in Slovenia are not taking the ageing workforce seriously and are failing to seek out and implement sufficient strategies for the retaining, retraining and recruitment of mature workers. Moreover, it is argued that Slovenian employers have failed to recognise that they have a shrinking labour market despite all evidence to support this. So, the conclusion from this research can be that even though Slovenian employers experience and/or expect labour market shortages they do not turn massively to older workers as a solution.

\section{CONCLUSIONS}

The implications of ageing populations in Slovenia are becoming important not only in terms of a slowdown in living standards but also with regard to employment, fiscal and other economic policies, especially as many structural reforms are still missing.

Public discussion about employment initiatives for an older workforce came to the political agenda at the end of the 1990s when issues of the employment of older persons became a part of active employment policy aiming at stimulating the creation of new jobs, employment of hard-to-employ persons and training and education for employment. However, the employment of older persons became one of the government's priorities only in 2004 and especially in 2005 when active employment policy schemes have been redirected towards addressing the problems of people aged over 55 .

National strategic and other documents, especially in the field of employment, indicate that the government of the Republic of Slovenia is aware of the problems arising from the ageing of the Slovenian population and workforce. Although there is a range of different measures aiming at the ageing workforce, the problems have been addressed mostly as a constituent part of the active employment policy and have not been - at least untill recently harmonised at a national level. In order to achieve the EU goal of the $50 \%$ employment rate of people aged $55-64$ by 2010, the macro-economic approach is not enough. Even though many documents and acts were passed at a government level, experts suggest that age management on a company level has to be enforced. For increasing employment of the older workforce, policy measures should be (more) obligatory for employers and should also be aimed at awareness building and attitude changing of employers.

To get a clear picture of development of age management in Slovenia, we conducted an empirical research within Slovenian companies. The survey consisted of questionnaires being sent to 780 companies in Slovenia. A number of issues were raised in the survey, but the most pertinent to this paper were the findings concerning the degree to which employers implement measures or consider implementing measures aimed at retaining older staff. However, the mobilisation of the players is barely emerging. Half the respondents indicated that their organizations devote little or no effort to retaining their own older workers, and few employers are looking to attract retirees who may be looking for new employment possibilities. Company directors and the various players concerned are not necessarily equipped as they confront these new challenges. HR managers are starting to familiarise themselves with the concepts, methods and tools, but only a few large companies have gained some experience in this matter. The conclusion of our research is very clear, employers will have to develop more effective ways of managing their aging workforce to maintain operational continuity.

\section{AUTHOR INFORMATION}

Jana Žnidaršič, Ph.D. is teaching and research assistant at University of Ljubljana, Faculty of Economics. She was dealing for more than a decade with the issues of Slovenian educational system, with emphasis on implementation of new learning approaches in educational process; the research on this field - accompanied with entrepreneurial activity - was her mastery degree thesis. Recently, she is working on the issues of contemporary management, especially on age management, as ageing puts forward one of the greatest challenges for companies and society. She has been recently involved in some sound research projects about age management in Slovenian enterprises. Age management on organizational level - in the sense of assuring the possibilities as well as conditions for longer working life - is the research theme of her doctoral dissertation. 
Vlado Dimovski, Ph.D. is full professor at University of Ljubljana, Faculty of Economics, and ex-minister for labor, family and social affairs. In the year 1994, he completed his doctoral dissertation on management and business finance on Cleveland State University (USA) in which he was dealing with learning organization. After his arrival back to his homeland, he was deeply involved in the pedagogic work on the university, leading different research projects dealing with contemporary managerial paradigm, and also, he was playing an active role in policymaking, especially on the field of business and social affairs.

\section{REFERENCES}

1. Brooke L., Taylor P.: Older Workers and Employment: Managing Age Relations. Ageing and Society, 25(3), 2005. Pp.: 415-430.

2. Brooke L.: Human resource costs and benefits of maintaining a mature-age workforce. International Journal of Manpower, Vol. 24, No. 3, 2003. Pp.: 260-283.

3. Dimovski V., Žnidaršič J., 2006: Od koncepta zgodnjega upokojevanja k strategiji aktivnega staranja. Kakovostna starost, 2006, letn. 9, št. 1, pp. 2-14. In Slovenian.

4. $\quad$ Employment Service of Slovenia; Annual Report 2006. URL: http://www.ess.gov.si/eng/annaulreport/lp06/eng/01-podatki.htm.

5. Government of Slovenia: Strategic goals of labour market development up to 2006, employment policy and its implication progrsammes. 53 pgs. URL: http://www.ess.gov.si/eng/EmploymentDoc/STRATE.doc.

6. Ilmarinen J.: The ageing workforce - challenges for occupational health. Occupational Medicine, 56(6), 2006 a. Pp.: 362-364.

7. Ilmarinen J.: Towards a longer worklife! Ageing and the quality of worklife in the European Union. Finnish Institute of Occupational Health. Helsinki: Ministry of Social Affairs and Health, 2006. 467 pgs.

8. Jouhette S., Romans F.: Labour market. Statistics in focus - Population and social conditions - 9/2005. Eurostat, 2005. URL: http://epp.eurostat.cec.eu.int/cache/ITY_OFFPUB/KS-NK-05-009/EN/KS-NK-05009-EN.PDF

9. Jouhette S., Romans F.: Labour market. Statistics in focus - Population and social conditions - 13/2006. Eurostat, 2006. URL:http://epp.eurostat.ec.europa.eu/cache/ITY_OFFPUB/KS-NK-06-013/EN/KS-NK06-013-EN.PDF

10. Kajzer A.: Delne zaposlitve so priložnost za prožnejši trg dela. Ljubljana: Finance, petek, 12. Avgust 2005, št. 156, p. 9. In Slovenian.

11. Kajzer A.: Fleksibilnost trga dela - o pojmu, dejavnikih in pomenu za zaposlenost in brezposelnost. Ljubljana: Urad Republike Slovenije za makroekonomske analize in razvoj. IB revija. Revija za strokovna in metodološka vprašanja trajnostnega razvoja. Št. 1-2 / letnik XXXVIII / 2004, pp. 108-116. In Slovenian.

12. Mandl I., Dorr A., Oberholzner T.: Age and employment in the new Member States. European Foundation for the Improvement of Living and Working Conditions. Luxembourg: Office for Official Publications of the European Communities, 2006. 84 pgs.

13. Mencinger J.: Spremembe na trgu delovne sile. Slovenska ekonomska revija, Ljubljana, 48 (1997), 1-2, pp. 151-165. In Slovenian.

14. Nunn A., Wymer P., Fidler Y.: Ageing \& Working. A report prepared for: The Fair Play for Older Workers Partnership. Leeds: Policy Research Institute, Leeds Metropolitan University, 2006. 69 pgs.

15. Pirher Sonja et al.: Background Study: Employment and labour market in Slovenia. 1st ed. Ljubljana: National VET Observatory Slovenia, 2000. 89 pgs.

16. Pušnik K. et al.: National Research Report Slovenia Employment Initiatives for an Ageing Workforce in the New Member States Plus Romania and Bulgaria. Study on behalf of The European Foundation for the Improvement of Living and Working Conditions. Maribor: Institute for entrepreneurship and small business management, Faculty of Economic and Business, University of Maribor, 2006. 51 pgs.

17. Remery C. et al.: Managing an aging workforce and a tight labor market: views held by Dutch employers. Population Research and Policy Review, 22, 2003. Pp. 21-40.

18. Van Dalen et al.: Dealing with an ageing labour force: What do European employers expect and do? The Hague: The Netherlands Interdisciplinary Demographic Institute (NIDI), 2006. 47 pgs.

19. Walker A.: Managing an Ageing Workforce. A Guide to Good Practice. The European Foundation for the Improvement of Living and Working Conditions, 1998. 24 pgs. 
20. Žnidaršič J.: Management starosti: organizacijski model aktivnega staranja. Doktorska disertacija. Univerza v Ljubljani, Ekonomska fakulteta, 2008. 362 pgs. In Slovenian.

\section{NOTES}

